\title{
AFFIRMATIVE BIOPOLITICS THROUGH THE ANALYSIS OF HOLOCAUST NARRATIVES: A LOOK AT FOUCAULT AND AGAMBEN
}

\section{OLUMLAYICI BIYOPOLITIKA TANIMININ SOYKIRIM ANLATILARI ÜZERINDEN INCELENMESI: FOUCAULT VE AGAMBEN'E BAKIŞ}

\section{Sel ERENSAL ${ }^{1}$}

\begin{abstract}
As one of the main components of the modern state, biopolitics appears to be a stable element behind each process of government. From early social contract theories to contemporary theories biopolitics has been a subject of various studies. Although it appears to be a fixed structure, it is possible to change the way it processes. Taking the theories of Foucault and Agamben, we arrive to the concept of the affirmative biopolitics. The affirmative biopolitics, a concept constructed by changing the destructive power of biopolitics to sustain human life, offers ways to overcome bio-power within the existing governmental structures. As it might come as a rather complex theory, it is a good idea to study affirmative biopolitics through the wellknown narratives, for better illustrative examples. Nazi regime is one of the most intense periods of biopolitical governance, thus, Holocaust narratives serve as a good point of departure for study. There are various examples of non-violent resilience against bio-power in these narratives. The common point of these narratives is reestablishing humanity, and, the first step for re-gaining a voice is through language. In terms of storytelling and testifying, language constructs a voice for the ones who were forced to silence. It is not testifying to the official truth but to the personal truth that alters the historical ground and shakes the bio-power. Then it is the comic attitude against the terror of destruction that might change the impact it leaves on people. It is possible to expand the branches of the affirmative biopolitics, yet these are effective practices that we can simply adopt to make an impact on the social processes around us.
\end{abstract}

Keywords: Foucault, Agamben, Affirmative Biopolitics, Holocaust Narratives, Non-violent Resilience.

\section{Öz}

Biyopolitika, modern devletin yapı taşlarından biri olarak, devleti oluşturan her tür mekanizmanın değişmez bir unsuru olarak karşımıza çıkıyor. İlk toplum sözleşmesi yasalarından çağdaş teorilere kadar türlü şekillerde bahsedilmiş biyopolitika, görünenin aksine kaçınılmaz bir gerçeklik olmak zorunda değil. Foucault ve Agamben'in teorilerini temel alarak olumlayıcı bioyopolitika tanımıyla karşılaşırız. Olumlayıcı biyopolitika, biyopolitikanın yıkıcı gücünün insan yaşamını sürdürecek doğrultuda değişmesi ile ortaya çıkmış, biyogücün mevcut iktidar sistemi dahilinde alt edilmesine işaret eden bir terimdir. Terime aşina olmak nispeten karmaşık olabileceğinden, olumlayıcı biyopolitikanın tanımı bilinen anlatılar üzerinden örneklenmesi doğru bir yaklaşım olacak. Bu çalışma için en uygun kaynak, biyopolitik yönetimin en sert olduğu Nazi dönemi olduğundan çalışma soykırım anlatıları üzerinden yürütülebilir. Bu anlatılarda biyogüce karşı gelen pek çok sessiz direniş örneği görebiliriz. Bu eylemlerin ortak noktası baskılanmaya çalışılan insanlığın yeniden inşa edilmesidir. Kişinin sesini, söylemini geri kazanmasının ilk yolu dilden geçer. Hikaye anlatıcılığı ve şahitlik gibi kollardan, dil, baskılanmış kişiler için yeniden bir ses oluşturur. Biyogücü sarsan bir diğer etken ise hakikattir. Kişinin, resmi gerçekliğe karşı kendi hakikatini dile getirmesi bilinen tarihi de etkileyerek, yeni bir tarih algısı oluşturur. Son olarak ise takınılan mizahi tavır, yıkımın insanlar üzerinde bıraktığı dehşeti yumuşatarak önemli bir silah haline gelebilir. Olumlayıcı biyopolitikayı daha da genişletmek tabii ki mümkün. Ancak bahsedilen eylemler, kolayca benimseyerek insanlığı çevreleyen bu gidişata karşı uygulayabileceğimiz davranışlar olabilir.

Anahtar Kelimeler: Foucault, Agamben, Olumlayıcı Biyopolitika, Soykırım Anlatıları, Pasif Direniş.

\footnotetext{
${ }^{1}$ MSc. Comparative Literature, University of Edinburgh, selerensal@gmail.com, https://orcid.org/0000-0003-0522-0507.
} 
In Roberto Benigni's movie, Life is Beautiful, we enjoy the happy ending. The scene freezes as the kid shouts in his mother's arms: "We won!" (min. 112) and the relief of the audience is supported by the feeling of victory. However, there is a problem at this point. Should we approach this as a happy ending or not? Not only at the final picture, but also at the final scenes, something does not fit right and requires further analyses. In the picture before the last, we see an American soldier riding a tank, following the survivors of the camp. In the next scene, as the camera angle changes, we watch the prisoners in front of a barrel. A question arises, is something really won? Are we talking about the end of an era and the beginning of another one, or do we need to look for more complex structures?

Labor camps of which the movie drags the audience right in the middle can be considered as the solid, physical space of biopolitics. Foucault mentioned the term for the first time in his lectures². Later, expanding Foucault's concept, Agamben constructed the theory of biopolitics. However, it is possible to see traces of the concept of biopolitics in the earlier social contract theories ${ }^{3}$. Referring to the way humans and human lives become subject to governance policies, the concept constitutes the core of political debates in the modern state. Biopolitics, in other words, points out how the governing body controls human life for the profit of the state. Yet, there is another concept, which is bound to the same idea that drops a hint on a more optimistic future: affirmative biopolitics. It is the power that transforms destruction and ruling over human life through new forms of living. While biopolitics holds the law, race and human life as weapons against humanity, affirmative biopolitics uses humor, storytelling and discourse as weapons that give the excluded a voice against the sovereign power. It is the reversal of the biopolitical power, a stance against spendable lives and re-inventing human subjectivity. Primo Levi's autobiographical novel If This is a Man and Roberto Benigni's movie Life is Beautifulare two of the instances that we can witness this transformative power. These works will be referred to visualize the theories of Foucault and Agamben.

The ending of Roberto Benigni's movie Life is Beautifu/requires deeper analysis rather than simply interpreting it's ending as a happy ending. This may be an ending

\footnotetext{
2See: Foucault, The Birth of Biopolitics: Lectures at the College de France, 1978-79; On The Government of The Living: Lectures at the College de France 1979-1980. In his earlier works, he was concerned with the bodies and pleasures, which set the ground for the development of the concept. See also, Foucault's The History of Sexuality.

${ }^{3}$ See: Hobbes, Leviathan. Considering Foucault's direct reference to Hobbes' theory, it is possible to take Hobbes' state of nature as a base for further conceptions of 'bare life,' sovereign power and 'state of exception' in the biopolitics jargon.
} 
according to the linear conception of history. The scene then would signify the end of an era and the beginning of another. However, through a Foucauldian perspective of history $^{4}$, it suggests a transformation of the existing power structures into new forms. As they continue their existence, the idea of a radical change becomes questionable. In his lecture dated 17 March 1976, Foucault mentions a shift in the sovereign power, which affects the idea of biopolitics in relation to this approach to history ("Society" 61-82). In the essay, Foucault mentions the difference between the two types of powers that the sovereign holds in ancient and modern democracies. While this power aimed to discipline the individuals in the pre-modern period, with modernity, it turns to society. The sovereign now aims to regulate the society instead of controlling the individuals (67). This way, Foucault defines the basis for modern sovereignty; people's right to live turns into the hegemon's right to "let live or expose to death" (Campbell and Sitze 3334, emphasis added). In the modern state, we face a sovereign who holds the power of exposing lives to death. This is not a direct act of killing that we are talking about here. "Sovereign power's effect on life," says Foucault, "is exercised when the sovereign can kill" (62). What it means is that the right to kill in the modern government does not refer to death, which is a natural process of life. It rather controls mortality. It is the opposite of death because the only way to establish its dominance is to show that it can manipulate this process: "Death was the moment of the manifestation of the obscure power of the sovereign" (Foucault "Society" 68). Consequently, in the modern state, the biopolitical structure, which claims a right on humans right to live, is still present in the center. Looking back to the movie through this perspective, the end of the Camps, the incident that symbolizes the end of World War II cannot be a victory or the end of an era. It just refers to a transformation of the existing dynamics. In this new order, the one who appears as the "bearer of rights" is the new hegemon, according to Foucault, who will exercise his power on other individuals (150). Practices of the previous regime are disguised under the structure of the modern state. Agamben also claims that we cannot see rapid, radical changes in between political structures. Therefore, a demolishment in the biopolitical order is not possible, we can only mention subtle changes and transformations (Agamben "Politicization" 147).

${ }^{4}$ See: Foucault, Archeology of Knowledge, 3-23. Foucault approaches history as transformation and continuation, rather than change and rupture. To reveal how and in which forms does the past continues in the present should be the main concern of a historical reading. 
With the outlined structure of the modern state, the idea of a social change might seem in deadlock. Does this motive of diminishing human subjectivity lie under each and every action of the modern sovereign? How can it be affirmative then? Agamben, through expanding Foucault's notes on the matter, provides a clearer view. What he finds missing in Foucault is a concrete theory, so he first aims to build one by depending on Foucault's idea of the power shift. He describes the Nazi regime and labor camps as the embodiment of biopolitics while depending on Walter Benjamin, and re-works his theories ${ }^{5}$ in order to address affirmative biopolitics.

First, the main point where Agamben parts from Foucault is where he separates biopolitics from the regulative institutions, human sciences, and capitalist processes in Sovereign of the Bare Life (Mills 59). Thus, biopolitics, which we see as a normalization mechanism in Foucault, operates through exclusion. It works to create a division in Agamben as he says that the "original activity" of biopower ${ }^{6}$ is the "production of biopolitical body" (in Mills, 59). To be able to do that, he distinguishes the biological and political lives of humans and defines bare life, a life stripped from all political rights and humane qualities, as the main object of this system. Another concept that differs between Foucault and Agamben is the notion of the law. The regulative notion of the law in Foucault becomes a force that creates the state of exception ${ }^{7}$ (62). Catherine Mills refers to this state where biopolitics operates as a "paradox" (62). It is included in the law as its creation, but the law does not apply to this sphere. State of exception is created through the "suspension of law" in which the legal orders does not process (62). This state is created by the law, when it is not regulated and the sovereign decides who will be excluded from the legal order and who will be treated in this state (61-62). For Agamben, homo sacer is the subject of this exclusion process and belongs entirely to the state of exception. As law does not operate to cherish or protect his/her rights, homo sacer can be killed or used in any way for the sake of the state. He/she is the ultimate

\footnotetext{
${ }^{5}$ See: Benjamin, Towards the Critique of Violence, 1921 and, Agamben, On the Limits of Violence, 1970.

${ }^{6}$ See: Rabinow. It is the result of the politicization of the human body and human species. The human body becomes an "object of manipulation and control" as well as fertility, death or health. Sovereign power then turns in "administration of bodies and calculated management of life" (17; 262).

${ }^{7}$ Carl Schmitt is also a substantial name on the 'state of exception'. He takes it as a rather broad term. There aren't any determinants to suggest what is the 'exception' and when to 'suspend' the law. Thus, the sovereign power first determines what is the danger, the exception, and how the regulations should be suspended to eliminate this danger. It is through the creation of we/them conflict. See: Schmitt, Political Theology.

8 See: Agamben, Homo Sacer. "...who may be killed and yet not sacrificed..." (8). Who is recognized by the state only for his/her "capacity to be killed" (8).
} 
figure that reveals the most fundamental political connection between the state and the human as it "recalls the memory of the exclusion that found in the juridico-political sphere" (72).

Agamben refers to the labor camps as the embodiment, the physical reality of the biopolitical world. Camps, for him, were the prototypes of the concept (Homo Sacer 2-8). Even before we come to Agamben, race politics appears in Foucault. In Society Must Be Defended, he questions the destructive nature of biopolitics by asking how an order that claims to favor human life operates through concepts such as death and exclusion ("Society" 73). Race politics becomes significant at this point. Biopower that functions to regulate the society through birth, death, health and such requires distinctive groups in order to build a dominance structure. It needs to emphasize the normal and the abnormal. Race makes it possible to make this division. Race politics, therefore, separates society into genders, races, and species according to biological codes. Then the sovereign can decide which group will be normalized and who needs to be regulated through the law. Thus, race politics works as a justification and as a motivation for the sovereign's right to kill. It is the "precondition for exercising the right to kill" ("Society" 75). It builds a life-death relationship between the sovereign and the society suggesting: "if you want to live the other must die" (74). After all, race politics provides sufficient ground for biopolitical order to function. Likewise, race politics depends on the biopolitical state. Making it possible to "exposing a whole race to death" (79) in the Nazi regime, biopower is spread among all the members of the society along with the sovereign. Practices that claim a right over the other lives could be performed not only by the sovereign but by a group of people. Camps were the "materialization of the state of exception" (Agamben "Politicization" 147) because they were the physical places where the homo sacer was held captive. In the camps, binary oppositions, friendenemy, good-bad, and so on, were created and actualized. This is a point we can extract from Benigni's movie. At the beginning of the movie, we see a communication, a relationship between Guido Orefice and Doctor Lessing. However, when they encounter again later in the camp, we see a clear limit in between their relationship. While they were equals in their previous encounters, now in the camp, the doctor is in the position of the master. He is willing to reciprocate Guido's attempt to communicate, however, he is banned through the law (min. 80-83). The friendship is banned through the laws that operate in this state of exception and a relation of power dominance is established 
instead. People thrown in state of exception are stripped from their human rights to live, to be equals and such, and degraded into living beings only. Their right to live is undermined and the practices of the power figures determine the life processes. Through this deprivation of rights, the sovereign builds dominance and total control over the captives in the camps. What Agamben expresses in the Sovereign of Bare Life is Nazi biopolitics, eugenics, practices of the biopolitical power on certain groups and certain people. In the modern state, however, everyone becomes a potential homo sacer, biopower can apply to every people in the society.

Thus far, biopolitics seems like a common structure surrounding human lives and holding rights as a weapon that can be used against humanity at any time. The question raises at this point, is there really no way out of this order, isn't there a way of reconstructing and sustaining human lives within this structure?

Appealing Agamben's understanding of affirmative biopolitics we can see possible ways of sustaining life within biopolitics. With the simplest explanation, Agamben suggests that this is possible by removing the distinction between political and biological lives, creating a politics of biological lives (Prozorov "Living" 5). This resolution, however, cannot be presented by a democracy. In a democracy, oppositions are possible. In a biopolitical structure, on the other hand, as people are deprived of all humane qualities, it is not possible to voice any resistance (7). Agamben brings up theories of language and discourse depending on Benjamin's storyteller ${ }^{9}$, to make the resistance possible. He suggests that turning bare life into good life is key to establish affirmative biopolitics (Agamben "Introduction" 139). Language is one way of accomplishing so. It is a humane quality as it makes it possible to voice the difference between good and bad, just and unjust (139). According to Benjamin, speech and/or writing mean a non-violent resilience and this works as a "divine power" (Boever 88). Storytelling, in this case, can be the transformative force that Agamben is looking for. Approaching Primo Levi's If This is a Man with this understanding, we can say that it affirms the horror of camps by turning his experiences into a narration. Levi, as a witness of the period, is someone who can enlighten what was happened. This way, the narration becomes a "testimony" instead of storytelling (Mills 89). Although the telling of the

${ }^{9}$ See: Walter Benjamin, The Storyteller. Benjamin approaches the art of storytelling in the same way as he approaches his beloved aura. It is unique to living beings, yet its importance can only be understood when it is no longer available. Likewise, the storytelling belongs to the witnesses of time and space and, can have value only after that time and space is buried in the past. The storyteller earns a voice within the communal past and writes his or her side of the history. 
events cannot change the past, it can be a valuable source that emphasizes injustice and inhumanity. Biopower aims to degrade people from "speaking beings" to bare life. Being able to tell the story of the camps not only explains the experience but also proves that the power was not successful. The survivors are still humans after all. Speech/language converts the bare life into a form of life with a human quality (89). Another important role of language is seen through the pronouns in Levi's narration. In the novel, he constantly uses the "we" language. Mills mentions the "I" pronoun, as a constructive expression, not an othering language, as it means that the narrator is also the subject of the discourse. The narrator is in the discourse alone. Levi, on the other hand, uses the "we" language. It stresses the fact that he was not alone in his experience and everything he is telling did happen. Along with re-humanizing himself, he also claims the humanity of the others as well. Thus, he stresses subjectivity.

Another constructive force within biopolitics is "shame" according to Agamben (Mills 90). Mills suggests that this is not caused by a lack. On the contrary, this is a shame of being "in a vision which one seeks to hide" (90), being exposed in an undesirable way. In If This is a Man, we can see that he uses the word "shame" quite often. He describes their clothes as "shameful clothes" while they are waiting for the examination (Levi 119). He says that they "sink into the ground from shame and embarrassment" in front of the girls in the laboratory because of the way they looked (Levi 167). He says how they were "oppressed by shame" (Levi 178). Under the Nazi regime, stripped from their humanity, they are stuck in an identity of being unworthy which they cannot break free. Yes, they may not be able to physically get out of this representation but having shame proves that their humanity is still present. This form of shame is what makes the creation of testimony possible (Mills 93).

The same concept, the importance of storytelling for affirmative biopolitics, can be applied to Roberto Benigni's movie as well. Although we don't see the testimonial quality of the movie or its emphasis on shame, it raises resistance against the order we are mentioning. The character Guido Orefice is the figure of the storyteller. Mills suggests that Benjamin associates the act of storytelling with concepts such as "law, justice, right" (Boever 87). He puts myth, which symbolizes the law, against the story and explains these concepts by revealing their associations with the other elements of the story. As I will be analyzing the movie through this perspective, I will be mentioning the figures of the youth and the fool. The figure of the foolmeans, "how mankind acts dumb 
towards the myth" (Benjamin "Illuminations" 102). In the movie, this figure corresponds to Guido Orefice, as he is constantly in this practice of storytelling. Considering that the myth refers to the law, telling a story works as a resistance against the biopolitical law, which rejects and degrades humanity. It provides a non-violent source of rebellion. Guido, through his stories, undermines the severity of the situations he is in and creates his own reality within the existing order. With his own reality, he manages to keep his humane self. The little kid, Giousé Orefice, according to the same theory, can be identified with the figure of the youth. The figure "sets out to learn what the fear is, it shows that the things we are afraid of can be seen through" (102). Giousé manages to survive through the most horrific conditions believing that the surrounding reality is just a game. Guido teaches him not to fear the conditions he is facing; therefore, he approaches everything in a positive manner. This is the most important thing that got him through the camps. Again, we see a failure of biopower in its attempt to dehumanize the individual. As he does not develop a fear of death, the dominant power could not claim a right over his life. Between these two figures, the act of storytelling teaches meeting "the forces of the mythical world with cunning and high spirits" (102). If biopower were a force of the mythical world, the law, adopting a smart, artsy approach to the world would provide safety. It makes it possible to transform the system that operates around death and exclusion to the other way. Being related to narration and language indirectly, humor appears as another way of the affirmative biopolitics. The theme is processed intensely in Life is Beautiful. We see Guido in a humorous approach throughout the movie. This comedic sight may have saved his kid's life in the end. The figure of the fool is a rebellious stance against injustice, as we have said. At the same time, this identity carries a discursive quality to homo sacer, whose speech has been taken away. Humor, a cynical style, might make Guido seem unrealistic or careless but the humor in the movie works as a source of alienation. It distracts the audience from the seriousness of the context just to be able to strike with reality more intensely. To exemplify, the race speech Guido gives at the school may look ridiculous. Or when Giouse asks about why Jews and dogs are not allowed, the answer he gives is that it could be anything like Chinese and kangaroos (min.50-51). We may think that he is undermining the reality, however, the central point he is making is that the "race" is something made up, something that relies on abstract assumptions about differences and similarities between people. However, the race is the main reason for all the tragedy happening later in the movie. Humor works in favor of affirmative biopolitics exactly 
because of this reason. While it is forbidden to have a speech, humor can disguise the rebellious and makes it possible to raise a voice. Through a cynical approach, people can express themselves freely even when their ability to speak is restricted.

Humor, storytelling, and language are significant for Agamben's affirmative biopolitics. According to Sergei Prozorov, Foucault also mentions this significance in his lecture dated 17 March 1979. Although he does not use the term affirmative biopolitics, he suggests that it is accurate to interpret the passage in this sense. The emphasis is on the way truth is delivered this time and the Cynics. He suggests that there is an opposition between biopolitical governmentality and affirmative biopolitics of parrhesia ${ }^{10}$. One expresses a lack, exclusion; the other is constructive, productive (Prozorov "Foucault's" 818). If we consider Guido as connected to the Cynic character, we can interpret his humor as a way of parrhesia.

According to Agamben, a way of affirming biopolitics was to build a true-life from in the condition of bare-life, finding the "power of the powerless" in other words (Prozorov "Foucault's" 817). The aim is to bring a new perspective, a new understanding to the existing order. Prozorov suggests by mentioning the Cynic practice of parrhesia that Foucault refers to this issue exactly. His theory emphasizes that expression of the truth can provide power for someone to claim his rights back. Humor, according to Agamben, is a way to save lives from sovereign dominance as it makes it possible to criticize biopolitical structures and their cruelty (Prozov "Foucault's" 804). However, as I have stated earlier in the essay, homo sacer stripped from the use of language is not allowed to do this openly. Thus, a new approach to living and a new discourse to express this new form of living needed to be established. Foucault suggests that Cynics and their way of approaching reality can provide a "biopolitical resistance to biopower" (805). In the order of the sovereignty, telling the truth in a mocking attitude seems like the only possible way of resistance (807-8). Affirmative quality, cynic parrhesia, connects with the movie I am mentioning, and the Nazi regime, in general, is the concept of bare-life. In the theory we are mentioning, humans were excluded from the order of law and reduced to the condition of bare-life, where they were considered as animals, not humans. What cynics manage to transform is exactly this sphere. This area is the base to reflect what is real and what is natural (" 810). They aim to create an alternate reality, an alternative way of living within the existing order (812). In Life is Beautiful, we can 
see Guido creating his own reality by his way of approaching the harsh reality. He expresses the reality in a way he would like to see. At the caps, at the state of exception, he manages to transform the deathly, destructive forces of biopolitics and saves his son's life. The Cynic figure does not aim to prove his existence, he wants to create his own reality against the governmental one and survive this way (Prozorov "Foucault's" 816). Turning to Levi, his narratives voice the truth in his perspectives. His narrative is not history, it is a biography, it is the reality Levi creates. He reveals his most unsecure moments and transforms them into a source for power by offering the truth against the common history. It is his way of affirming the ordeal, not denying but altering it.

Behind the modern state and each and every one of its power structures, there is biopolitics that claims peoples' rights to live and turns it into a weapon to hold against society. It might appear as a stable component of socio-political life, regardless of the structural changes. The contemporary concept of history, transformative and continuative, suggests that each reformation, each progress build upon the same biopolitical skeleton. Then are we giving up against what feels like an imperious future? I hope this paper served as an indicative of possible steps one can take to transform this conduct. While we would only butter the bread of the sovereign power with mass reactions or with violent responses, there are micro actions to take. It is possible to see that everything is a weapon if we hold them right ${ }^{11}$. It is speech to reflect the self, and language to reclaim humanity. Then it is storytelling to rebuild what has been destructed, thus, alter the past. Yet the most important tool to dethrone biopolitical practices is humor. Such subtle resilience is the key to an alternative order that overcomes the exception, reinvents the rights and equality, thus sustains human life. Now, then, what is left for us is to devote to these micro-political ${ }^{12}$ practices to affirm the obliteration, to live, and to let others live in a more harmonious future.

\footnotetext{
${ }^{11}$ Quoting Ani DiFranco. My $1 Q$.

${ }^{12}$ It is not possible to talk about the term more in depth within the scope of this paper. Briefly, micro-politics is about union of opposite poles around the same goals. It is creation of alternate communities, which would shake the stable grounds of opposition and conflict that supports the power systems.

For a brief introduction, see: Anderson, "Hope and Micropolitics".

For more, see: Gilliam, Immanence and Micropolitics.
} 


\section{WORKS CITED}

Agamben Giorgio, Homo Sacer: Sovereign Power and Bare Life. translated by Daniel Heller-Roazen. Stanford University Press, Stanford, California, 1998. pp 1-12.

Agamben, Giorgio. "Introduction to Homo Sacer: Sovereign Power and Bare Life". Biopolitics: A Reader, edt. T. Campbell, A. Sitze. United States, 2013. Pp. 134145.

Agamben, Giorgio. "The Politicization of Life”. Biopolitics: A Reader, Edt. T. Campbell, A. Sitze. United States, 2013. pp. 145-152.

Agamben, Giorgio. "On The Limits of Violence". Diacritics, Vol 39, issue 4, 2009.edt. Lorenzo Fabbri. John Hopkins University Press, 2012. pp 103-111.

Anderson, Ben. "Hope and Micropolitics". Sage Journals, Environment and Planning D: Society and Space, Vol 35, Issue 4, August 2017, Pages 593-59.

Benjamin, Walter. "Critique of Violence". Walter Benjamin: Selected Writings Volume I: 1913-1926, edt. Marcus Bullock, Micheal W. Jennings. The Belknap Press of Harvard University Press, United States, 2004. Pp 236-253.

Benjamin, Walter. I/luminations. Trans. Harry Zohn. New York, 1968. Pp. 83-109

Benjamin, Walter. "The Storyteller". Walter Benjamin: Selected Writings Volume III: 1935-1938. Edt. Howard Eiland and Micheal W. Jennings. Cambridge; London: Harvard University Press, 2002.

Boever, Arne de. "Politics and Poetics of Divine Violence: On a Figure in Giorgio Agamben and Walter Benjamin", The Work of Giorgio Agamben: Law, Literature, Life, edit. J. Clemens, N. Heron, A. Murray. Edinburgh, 2008. Pp. 82-97.

Campbell, Timothy and Sitze Adam. "Biopolitics: An Encounter". Biopolitics: A Reader, edt. T. Campbell, A. Sitze. United States, 2013. Pp. 1-40.

Foucault, Michel. “'Society Must be Defended', Lecture at the Collége de France March 17, 1976". Biopolitics: A Reader, edt. T. Campbell, A. Sitze. United States, 2013. Pp. 61-82.

Foucault, Michel. Archeology of Knowledge. Trans. A.M. Sheridan Smith. London: New York, Routledge, 2002. Pp 3-23. 
Foucault, Michel. The Birth of Biopolitics: Lectures at the Collége de France, 1978-79. Edt Michel Senellart, François Ewald, Alessandro Fontana trans. Graham Burchell. Hampshire, Palgrave Macmillan Press, 2008.

Foucault, Michel. On The Government of Living: Lectures at the Collége de France, 1979-80. Edt, Michel Senellart, François Ewald, Alessandro Fontana, trans. Graham Burchell, Hampshire, Palgrave Macmillan, 2014.

Foucault, Michel. History of Sexuality. Trans. Robert Hurley. London, Penguin, 1979-1990.

Gilliam, Christian. Immanence and Micropolitics: Sarte, Merleau-Ponty, Foucault, Deluze. Edinburgh University Press, 2017.

Hobbes, Thomas. Leviathan. Minneapolis, First Avenue Editions; Lerner Publishing, 2018, E-Books.

La Vita é Bella. Directed by Roberto Benigni. Melampo Cinematografica, 1997.

Levi, Primo. If This is a Man. Trans. Stuart Woolf. New York, 1959. E-book.

Mills, Catherine. The Philosophy of Agamben. Acumen Publishing, 2008. pp 1-9, 81-133.

Prozorov, Sergei. "Foucault's Affirmative Biopolitics: Cynic Parrhesia and the Biopower of the Powerless". Political Theory, 2017, vol 45/6, pp. 801-823.

Prozorov, Sergei. "Living a la mode: Form-of-life and democratic biopolitics in Giorgio Agamben's use of Bodies". Philosophy and Social Criticism, 2017, vol. 43/2, pp. 144-163.

Rabinow, Paul. The Foucault Reader. Edt. Paul Rabinow. Pantheon Books, New York 1984.

Schmitt, Carl. Political Theology: Four chapters on the concept of sovereignty. Trans. George Schwab. Chicago;London, University of Chicago Press, 2005. 